\title{
Acute syphilitic chorioretinitis after a missed primary diagnosis: a
}

\section{case report}

\author{
Claudia Handtrack ${ }^{1}$, Harald Knorr², Kerstin U Amann², \\ Christoph Schoerner ${ }^{4}$, Karl F Hilgers ${ }^{1}$ and Walter Geißdörfer*4
}

\begin{abstract}
Address: ${ }^{1}$ Department of Nephrology and Hypertension, Krankenhausstraße 12, 91054 Erlangen, Germany, ${ }^{2}$ Department of Ophthalmology, Schwabachanlage 6, 91054 Erlangen, Germany, ${ }^{3}$ Institut of Pathology, Krankenhausstraße 8, 91054 Erlangen, Germany and ${ }^{4}$ Institut of Clinical Microbiology, Immunology and Hygiene, Wasserturmstraße 3, 91054 Erlangen, Germany

Email: Claudia Handtrack - claudia.handtrack@gmx.de; Harald Knorr - harald.knorr@augen.imed.uni-erlangen.de; Kerstin U Amann - kerstin.amann@patho.imed.uni-erlangen.de; Christoph Schoerner - schoerner@mikrobio.med.uni-erlangen.de; Karl F Hilgers - karl.hilgers@ rzmail.uni-erlangen.de; Walter Geißdörfer* - walter.geissdoerfer@mikrobio.med.uni-erlangen.de

* Corresponding author
\end{abstract}

Published: I February 2008

Journal of Medical Case Reports 2008, 2:33 doi:10.1186/1752-1947-2-33
Received: 13 July 2007

Accepted: I February 2008

This article is available from: http://www.jmedicalcasereports.com/content/2/1/33

(C) 2008 Handtrack et al; licensee BioMed Central Ltd.

This is an Open Access article distributed under the terms of the Creative Commons Attribution License (http://creativecommons.org/licenses/by/2.0), which permits unrestricted use, distribution, and reproduction in any medium, provided the original work is properly cited.

\begin{abstract}
Introduction: Syphilis is well known as an infectious disease which can present with a large variety of symptoms. Clinical diagnosis can be difficult and may be complicated in modern medicine by immunosuppressive treatment and possible side effects of medication.

Case presentation: We describe a rare case of placoid chorioretinitis due to Treponema pallidum which developed after the primary symptom of proteinuria was not recognized as a rare manifestation of syphilis. Diagnosis of syphilitic chorioretinitis and/or endophthalmitis was made by broad range amplification of the bacterial $16 \mathrm{~S}$ ribosomal RNA gene obtained from vitreous after diagnostic vitrectomy.

Conclusion: This case shows that clinicians should be alert in patients with proteinuria and chorioretinitis as they can represent rare manifestations of syphilis. Syphilis should be in the differential diagnosis of any unknown symptom and in the presumed side effects of medication.
\end{abstract}

\section{Introduction}

Primary syphilis is characterized by a single cutaneous or mucosal lesion (hard chancre) at the site of infection, which is self-healing, but frequently followed by the secondary, disseminated stage with a variety of possible symptoms, including maculopapular rashes, mucous patches in the mouth, genital condylomata, alopecia, malaise with fever, and, in less than one percent of the cases, renal or ocular manifestations [1]. Laboratory diagnosis of syphilis by serological tests is well established, highly sensitive and specific.
Within the last decade a rising incidence of syphilis in the Western World has been reported, especially among men who have sex with men [2]. Today, the knowledge of even rare manifestations of the disease and the awareness of its increasing epidemiological relevance remain the key requirement for a correct and rapid diagnosis of Treponema pallidum infections by physicians. This problem is illustrated by our patient, who developed syphilitic chorioretinitis after the initial diagnosis of proteinuria was thought to result from focal segmented glomerulosclerosis (FSGS) and who was treated with immunosuppressive doses of prednisolone. 


\section{Case presentation}

A 35-year-old female patient with a medical history of myasthenia gravis, who was treated for more than 20 years with pyridostigmine, was admitted to our department of ophthalmology because of acute loss of vision. Three months prior to admission the patient suffered from bronchitis, accompanied by puffiness and ankle edema, presumably due to nephrotic range proteinuria, and arthralgias. Furthermore, she noted an intermittent exanthema on the flexor sides of both arms, on her calves and on the chest below her breasts. Her general practitioner found a nephrotic range proteinuria $(9 \mathrm{~g} / \mathrm{d})$, subfebrile temperatures and a very high erythrocyte sedimentation rate of $22 \mathrm{~mm}$ per hour. Two weeks later she was referred to our nephrology department for an elective renal biopsy, which, unfortunately, did not yield a clear diagnosis upon immuno-histopathological examination. Mild mesangial hypercellularity and interstitial leukocyte infiltration were interpreted as being compatible with an early stage of primary focal segmented glomerulosclerosis (FSGS). The patient was treated with an angiotensin-converting enzyme inhibitor, a statin, and prednisolone (1 $\mathrm{mg} / \mathrm{kg}$ bodyweight, i.e. $60 \mathrm{mg} / \mathrm{d}$ ) and seen regularly for follow-up visits in the outpatients' clinic.

One month after the onset of therapy the patient started suffering from severe stomatitis with the detection of Candida albicans, which was locally treated with an amphotericin $\mathrm{B}$ suspension. At that time the proteinuria had improved and was $1 \mathrm{~g} / \mathrm{d}$. One week later the patient showed multiple oral aphthous lesions, from which herpes simplex virus (HSV) DNA could be amplified. The patient therefore was treated with oral aciclovir. She also reported hoarseness and loss of hair which were interpreted as side effects of the steroid therapy, and a maculopapulous exanthema of the palms which was diagnosed
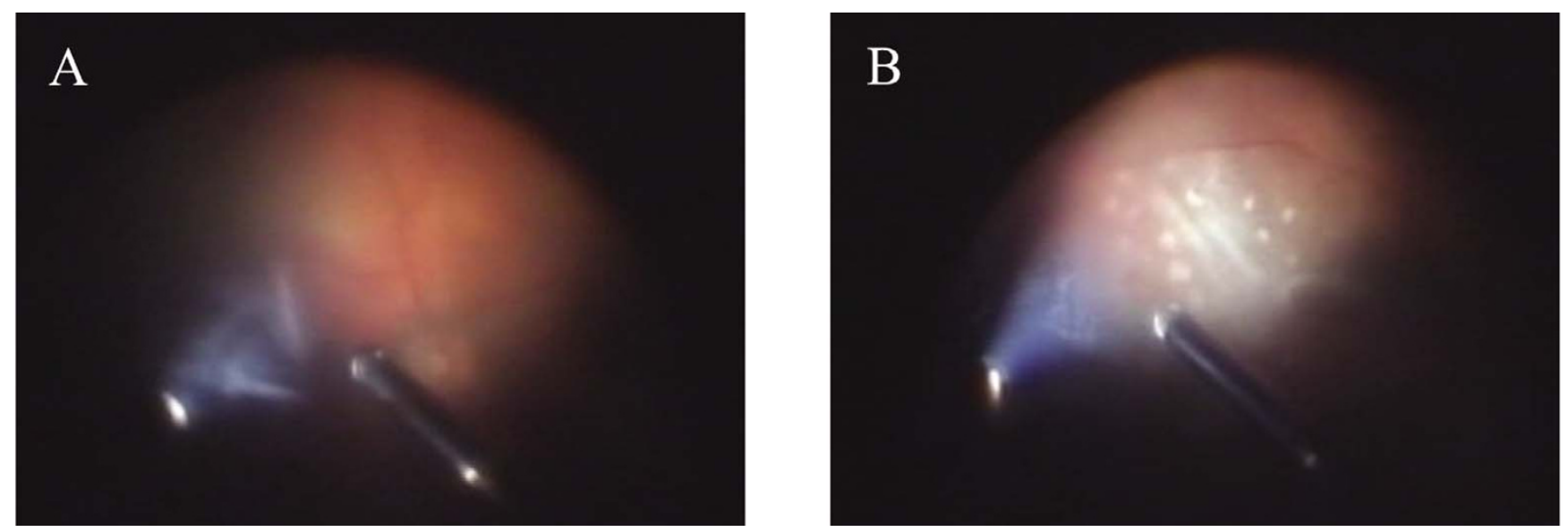

Figure I

Findings during vitrectomy. (A) Whitish cloudy cords. (B) Retinitis with multiple ill-defined spots. 
Table I: Serological assay results at primary diagnosis and follow-up

\begin{tabular}{|c|c|c|c|c|c|c|}
\hline \multirow[t]{2}{*}{ Assay } & \multicolumn{6}{|c|}{ Time of serological diagnosis } \\
\hline & Primary diagnosis & I month & 3.5 months & 9.5 months & I year 4 months & I year 8 months \\
\hline TPPA & $\mathrm{I}: 10240$ & $\mathrm{I}: 2560$ & $\mathrm{I}: 1280$ & $\mathrm{I}: 320$ & $\mathrm{I}: 320$ & $1: 160$ \\
\hline FTA-Abs & pos. & n.d. & n.d. & n.d. & n.d. & n.d. \\
\hline IgM FTA-Abs & $1: 80$ & $\mathrm{I}: 10$ & neg. & neg. & n.d. & n.d. \\
\hline Cardiolipin CFR & $1: 320$ & $1: 160$ & $1: 80$ & $1: 20$ & I:5 & 1:5 \\
\hline
\end{tabular}

CFR, Complement-fixation reaction; FTA-Abs, fluorescent treponemal antibody absorptions test; TPPA, Treponema pallidum particle agglutination assay; n.d., not determined; neg., negative; pos., positive.

prior to the acute loss of vision as the possible time of infection. A syphilitic chancre was not noticed by the patient.

\section{Discussion}

In this case of a 35-year-old female patient, diagnosis of syphilis was only made after diagnostic vitrectomy. The initial symptom of our patient was a nephrotic range proteinuria of unknown origin. Kidney involvement in Treponema pallidum infection occurs in various forms including nephrotic syndrome [3], membranous [4], or minimal change glomerulonephritis [5], but is rare and not highly indicative of syphilis. Unfortunately, the majority of the other primary clinical symptoms, which, retrospectively, were most likely caused by the infection with T. pallidum, were either non-specific and/or could be interpreted as possible side effects of the concurrent medication: bronchitis, arthralgia, erythema, loss of hair. Moreover, there was laboratory evidence supporting the diagnosis of an intermittent viral infection (HSV). Only the severe complication of chorioretinitis that required hospital admission and the lack of response to antifungal and antibacterial treatment necessitated vitrectomy and further diagnostic tests. The cellular infiltration of the vitreous and the white retinal spots, combined with the patient's recent history of $C$. albicans stomatitis and immunosuppressive treatment, strongly suggested infectious, most probably mycotic, endophthalmitis. Finally, universal bacterial PCR led to the diagnosis of syphilitic placoid chorioretinitis. This method has proven a very useful diagnostic tool, because even non-culturable and non-viable bacteria after antibiotic treatment can be detected [6]. Detection of Treponema pallidum DNA by specific PCR in vitreous specimens has only recently been reported for the first time $[7,8]$. Diagnosis of syphilis by PCR is especially required and reasonable in select cases, when serological assays are of limited use or when the infection of a given organ system needs to be confirmed [9].

Manifestations of ocular syphilis are manifold and are predominantly found in HIV-positive or immunosuppressed patients [10], but it is not clear, if this just reflects the higher prevalence of syphilis within these groups, or if modification of the immune system really promotes infection $[11,12]$. Our patient was HIV-negative, but was under mild immunosuppression for supposed FSGS. In a previous study Treponema pallidum DNA was detected in a quarter of spinal fluid samples from patients independent of their HIV status, and more often in early syphilis (40 $\%)$ than in secondary (23\%) or early late stage $(20 \%)$. This indicates that invasion of the CNS is common in syphilis [13]. Considering its known hematogenous dissemination, it is not surprising that Treponema pallidum can also be found in vitreous. The detection of Treponema pallidum DNA in the vitreous of our patient and the rapid response to treatment with penicillin $G$ strongly suggests that the fulminant intraocular pathology seen in our patient was directly related to the presence of viable Treponema. Likewise, the complete remission of proteinuria after penicillin treatment without further corticosteroid therapy combined with the observation that nephrotic-range proteinuria did not re-occur after more than two years, points towards initial syphilitic nephropathy.

\section{Conclusion}

In conclusion, this case illustrates the difficulties in diagnosing syphilis in a situation, where the initial manifestation of infection was unusual (mild nephrotic syndrome), obvious sexual risk factors like prostitution were absent, and more typical symptoms of syphilis (e.g., palmar erythema, hair loss) could be interpreted as medicationinduced complications. Considering the chameleonic behaviour of syphilis and its recent increase in the Western World [14], specific questioning and serological testing for syphilis should always be performed whenever the etiology of organ symptoms remains unclear.

\section{Competing interests}

The author(s) declare that they have no competing interests.

\section{Authors' contributions}

C Handtrack took care of the patient during hospitalization and drafted the manuscript. H Knorr performed oph- 
thalmoscopy and vitrectomy. KU Amann carried out immunohistopathological examination of the renal biopsy. C Schoerner performed the microbiological diagnostics. KF Hilgers participated in the patient's care and in drafting the manuscript. W Geißdörfer performed the molecular diagnostics and helped to draft the manuscript. All authors read and approved the final manuscript.

\section{Consent}

Written informed consent was obtained from the patient for publication of this Case report and any accompanying images. A copy of the written consent is available for review by the Editor-in-Chief of this journal.

\section{Additional material}

\section{Additional file 1}

Ophthalmoscopic findings during vitrectomy. The video shows the whitish cloudy cords and the white retinal spots found during vitrectomy.

Click here for file

[http://www.biomedcentral.com/content/supplementary/17521947-2-33-S1.mpg]

\section{Acknowledgements}

We thank C. Bogdan for critically reading the manuscript.

\section{References}

I. Tramont EC: Treponema pallidum (Syphilis). In Principles and practice of infectious diseases sixth edition. Edited by: Mandell GL, Bennet JE, Dolin R. Philadelphia , Elsevier; 2005:2768-2785.

2. Peterman TA, Furness BW: The resurgence of syphilis among men who have sex with men. Curr Opin Dis 2007, 20(I):54-59.

3. Kusner DJ, Ellner JJ: Syphilis--a reversible cause of nephrotic syndrome in HIV infection. N Engl J Med I99I, 324(5):34I-342.

4. Cahen R, Francois B, Trolliet P, Gilly J, Parchoux B: Aetiology of membranous glomerulonephritis: a prospective study of 82 adult patients. Nephrol Dial Transplant 1989, 4(3): I72-180.

5. Krane NK, Espenan P, Walker PD, Bergman SM, Wallin JD: Renal disease and syphilis: a report of nephrotic syndrome with minimal change disease. Am J Kidney Dis 1987, 9(2): I76-I79.

6. Relman DA, Schmidt TM, MacDermott RP, Falkow S: Identification of the uncultured bacillus of Whipple's disease. $N$ Engl J Med I992, 327(5):293-30I.

7. Müller M, Ewert I, Hansmann F, Tiemann C, Hagedorn HJ, Solbach W, Roider J, Nölle B, Laqua H, Hoerauf H: Detection of Treponema pallidum in the Vitreous by PCR. Br J Ophthalmol 2006, 91:592-595.

8. Rajan MS, Pantelidis P, Tong CY, French GL, Graham EM, Stanford MR: Diagnosis of Treponema pallidum in vitreous samples using real time polymerase chain reaction. $\mathrm{Br} J$ Ophthalmol 2006, 90(5):647-648.

9. Michelow IC, Wendel GD Jr., Norgard MV, Zeray F, Leos NK, Alsaadi $R$, Sanchez PJ: Central nervous system infection in congenital syphilis. N Engl J Med 2002, 346(23): I792-I798.

10. Tran TH, Cassoux N, Bodaghi B, Fardeau C, Caumes E, Lehoang P: Syphilitic uveitis in patients infected with human immunodeficiency virus. Graefes Arch Clin Exp Ophthalmol 2005, 243(9):863-869.

II. Gass JD, Braunstein RA, Chenoweth RG: Acute syphilitic posterior placoid chorioretinitis. Ophthalmology 1990 , 97(10): I288-1297.

12. Zamani M, Garfinkel RA: Corticosteroid-induced modulation of acute syphilitic posterior placoid chorioretinitis. Am J Ophthalmol 2003, I35(6):89|-894.
13. Rolfs RT, Joesoef MR, Hendershot EF, Rompalo AM, Augenbraun MH, Chiu M, Bolan G, Johnson SC, French P, Steen E, Radolf JD, Larsen S: $A$ randomized trial of enhanced therapy for early syphilis in patients with and without human immunodeficiency virus infection. The Syphilis and HIV Study Group. N Engl J Med 1997, 337(5):307-314.

14. Golden MR, Marra CM, Holmes KK: Update on syphilis: resurgence of an old problem. JAMA 2003, 290(I I): I5 I0-15 I4.
Publish with Bio Med Central and every scientist can read your work free of charge

"BioMed Central will be the most significant development for disseminating the results of biomedical research in our lifetime. " Sir Paul Nurse, Cancer Research UK

Your research papers will be:

- available free of charge to the entire biomedical community

- peer reviewed and published immediately upon acceptance

- cited in PubMed and archived on PubMed Central

- yours - you keep the copyright
BioMedcentral 